\title{
The insertion of the nurse midwife in delivery and birth: obstacles in a teaching hospital in the Rio de Janeiro state
}

\author{
A inserção da enfermeira obstétrica no parto e nascimento: obstáculos em um hospital de ensino no Rio \\ de Janeiro \\ Inserción de la enfermera obstetra en el parto y el nacimiento: obstáculos en un hospital de enseñaza en \\ el estado de Rio de Janeiro
}

Rosangela da Conceição Sant’anna

Amaral $^{1}$

Valdecyr Herdy Alves ${ }^{2}$

Audrey Vidal Pereira ${ }^{2}$ (i)

Diego Pereira Rodrigues ${ }^{2}$ (1)

Luana Asturiano da Silva²

Giovanna Rosário Soanno Marchiori ${ }^{3}$ (C)

1. Faculdade Arthur Sá Earp Neto. Petrópolis,

RJ, Brasil.

2. Universidade Federal Fluminense. Niterói,

RJ, Brasil.

3. Faculdade Novo Milênio. Espírito Santo,

ES, Brasil.
Corresponding author

Diego Pereira Rodrigues.

E-mail:diego.pereira.rodrigues@gmail.com.

Submitted on $07 / 31 / 2018$.

Accepted on 11/23/2018.

DOI: 10.1590/2177-9465-EAN-2018-0218

\begin{abstract}
Objective: analyze the insertion of the nurse midwife in a teaching hospital in Rio de Janeiro State. Method: descriptive, exploratory study of qualitative nature, study case type, carried out in a maternity in the mountain region, with nine healthcare professionals and six managers. The data collection occurred from December 2016 to March 2017, by semi-structured interviews that subsequently transcribed and submitted to content analysis in the thematic modality. Results: difficulties were observed for the insertion of the nurse midwife such as: lack of specialist nurses in the delivery room; absence of space for the professional autonomy; political partisans influence in the health management; acting conflict with the obstetricians; no team support, mainly with regard to workers qualification. Conclusion: this study shows the need for direct insertion of the nurse midwife in delivery and birth, especially valuing humanized care and autonomy for professional practice.
\end{abstract}

Keywords: Maternal and Child Health Services; Woman's Health; Delivery; Humanization of Assistance; Nurse Midwives.

\section{Resumo}

Objetivo: analisar a inserção da enfermeira obstétrica em um hospital de ensino no estado do Rio de Janeiro. Método: estudo descritivo, exploratório, de natureza qualitativa, do tipo estudo de caso, realizado em uma maternidade na Região Serrana, com nove profissionais de saúde e seis gestores. A coleta de dados ocorreu no período de dezembro de 2016 a março de 2017, por meio de entrevistas semiestruturadas que, posteriormente, foram transcritas e submetidas à análise de conteúdo na modalidade temática. Resultados: foram observadas dificuldades para a inserção da enfermeira obstétrica como: insuficiência de enfermeiras especialistas na sala de parto; ausência de espaço para autonomia profissional; influência político-partidária na gestão da saúde; conflito de atuação com médicos obstetras; falta de apoio da equipe, principalmente em relação à capacitação de trabalhadores contratados. Conclusão: o estudo mostra a necessidade de inserção direta da enfermeira obstétrica no parto e nascimento, sobretudo, valorizando o cuidado humanizado e a autonomia para o exercício profissional.

Palavras-chave: Serviços de Saúde Materno-Infantil; Saúde da Mulher; Parto; Humanização da Assistência; Enfermeiras Obstétricas.

\section{Resumen}

Objetivo: analizar la inserción de la enfermera obstetra en un hospital de enseñanza del Estado de Rio de Janeiro. Método: estudio descriptivo, exploratorio, de naturaleza cualitativa, del tipo estudio de caso, realizado en una maternidad en la Región Serrana, con nueve profesionales de la salud y seis gestores. La recolección de datos se realizó en el período de diciembre 2016 a marzo 2017, por medio de entrevistas semiestructuradas que, posteriormente, fueron transcritas y sometidas al análisis de contenido en la modalidad temática. Resultados: fueron observadas dificultades en la inserción de la enfermera obstetra como: insuficiencia de enfermeras especialistas en la sala de parto; ausencia de espacio para la autonomía profesional; influencia político-partidaria en la gestión de la salud; conflicto de actuación con médicos tocólogos y falta de apoyo del equipo, principalmente con relación a la capacitación de trabajadores contratados. Conclusión: el estudio muestra la necesidad de inserción directa de la enfermera obstetra en el parto y nacimiento, sobre todo, valorando el cuidado humanizado y la autonomía para el ejercicio profesional.

Palabras clave: Servicios de Salud Materno-Infantil; Salud de la Mujer; Parto; Humanización de la Atención; Enfermeras Obstétricas. 


\section{INTRODUCTION}

The paradigm that influences attention to delivery and birth to the present day was constructed, historically, from the eighteenth century, with the insertion of Medicine. From this period, the process of transition from the holistic model, in which women held power and autonomy over their body, to the institutionalized technocratic model constituted the transition process. This model of obstetric care has been in place in the country, favoring "the indiscriminate use of technologies and interventions, the practice of routine cesarean delivery, the violation of women's rights and the maintenance of high numbers of maternal mortality"1:1092.

Thus, obstetric care focused on the predominance of the use of unnecessary and harmful interventions to "consider delivery a medical and risk event whose setting is the hospital environment... and the birth a pathological event that needs to be treated"2:235, ends up disregarding women's autonomy and decision-making power, contributing to the surveillance and domination of the female body. In this context, "the performance of the nurse midwife had the primary merit of intensive surveillance and control of labor"3:02, dialoguing to some extent with the hegemonic practice of intervention of the obstetrician, characterized by the institutional emphasis and the technocratic model with the justification of making the birth event safer for the woman and the newborn ${ }^{4}$.

However, coupled with the process of democratization and social participation and the humanizing movement of delivery in the 80's, there are critical movements in this traditional way of care for the health of the woman and the newborn, making room for the nurse midwife direct care for delivery ${ }^{4}$.

Thus, in 1985, in line with the criticism of current obstetric care, the I Conference on Appropriate Technology for Birth, sponsored by the Pan American Health Organization (PAHO)/ World Health Organization (WHO), considered "an important milestone in the review of technologies used at birth and delivery, leading to the adoption of recommendations that contravene the inappropriate and indiscriminate use of invasive technologies at delivery"1:1092

In 1996, WHO "developed and published a classification of practices used in the conduct of vaginal delivery and birth, based on scientific evidence"1:1092. Significant useful practices such as right to follow up, freedom of position and use of non-pharmacological methods for pain relief were signaled; and others to be eliminated, such as enema, trichotomy and episiotomy. In addition, there was an incentive to perform training and the insertion of nurse midwives in the delivery and delivery care $^{1,2,5}$.

With the encouragement of the applicability of these recommendations, the insertion of nurse midwives was promoted in parallel, as the incisive participation of these professionals in the care of labor, delivery and birth strengthens their contribution to the practice of care, according to $\mathrm{WHO} / \mathrm{MoH}$ guidelines, in addition to qualifying the care provided and reducing the use of interventional practices ${ }^{1,2,4,6,7}$.
This emphasis on the insertion of the nurse midwife directly into the scene of the delivery and birth process has an important engagement for the implantation of the humanized model and a safe care with a scientific basis. In this way, in supporting the $\mathrm{WHO} / \mathrm{MoH}$ prerogatives, with emphasis on reducing unnecessary interventions, it contributes with mechanisms for the implementation of this model, whose focus is "respect", "effective communication", "continuity of care" and with processes responsible for reducing maternal morbidity and mortality rates ${ }^{6,7}$.

Thus, this study aimed to analyze the insertion of the nurse midwife in a teaching hospital in Rio de Janeiro state.

\section{METHOD}

A descriptive, exploratory study of a qualitative nature, of the case study type. As the qualitative research is directed to a level of reality that should not be quantified, highlighting values, symbols and meanings ${ }^{8}$, the same dialogue with the option given by the case study, making feasible an analysis of the object investigated, which makes it possible to deepen the social reality investigated through the collection of non-probabilistic information ${ }^{9}$. The case study is characterized by investigations of a single entity or small group (school, university, club, a social unit) ${ }^{10}$, being able to examine the relations of institutional daily life, thus serving as a background to dialogue with the vision of the study participants in the research process, including institutional relations or processes.

In this case, the study was carried out in a maternity unit in the Mountain Region of Rio de Janeiro state, Brazil, a public institution in that region that served users of the Brazilian Unified Health System (SUS - Sistema Único de Saúde) with a mean of 896.5 pregnant women/month ${ }^{11}$. This institution was identified as feasible to carry out this study, considering that it was undergoing historical changes related to the guidelines of the Ministry of Health $(\mathrm{MoH})$ regarding the insertion of the nurse midwife in the attention to delivery and birth.

Nine health professionals attending delivery and birth (seven nurses and two doctors) participated in the study; six managers (one Officer of Health, two Directors of the Hospital, Director of Human Resources, Hospital Administered, Coordinator of the Undergraduate Nursing Course). The inclusion criterion established was the professional participation in the historical process of insertion of the nurse midwife in the Health Unit. Exclusion criteria corresponded to health professionals and managers who were far from their duties and those who were no longer performing their job functions in the unit, since the hospital is a Municipal institution and, therefore, undergoes political interference in the change of management.

Data collection took place in the period from December 2016 to March 2017, through semi-structured interviews on the insertion of nurse midwives, which took place in a private environment, thus ensuring the privacy of the participant. The interviews ceased through the process of saturation of information. The statements were collected by digital apparatus, transcribed in full and submitted to content analysis in thematic 
modality ${ }^{12}$. In order to ensure the confidentiality and anonymity of the participants' statement, they were identified as 'Interviewee' and received a sequential alphanumeric code $(I 1, I 2, \ldots I 15)$ that were subsequently transcribed and submitted to content analysis in thematic modality.

Registration Units were used based on the themes identified in the speeches of the professionals and managers, as a strategy for organizing the content of the interviews. For that, different colors were selected, with the purpose of identifying each unit and grouping them, thus allowing an overview of the subject, originating the following Registration Units: "hiring nurse midwives"; "nurse midwife care"; "nurse midwife in risk classification"; "nurse midwife in hospital delivery"; "multiprofessional team and delivery in teaching hospital". These Registration Units enabled the construction of the thematic categories: "The insertion of the nurse midwife in the setting of teaching maternity"; and "Expressions of health professionals and managers on the insertion of the nurse midwife in delivery and birth".

The research was approved by the Research Ethics Committee of the Hospital Universitário Antônio Pedro, Universidade Federal Fluminense, under Protocol 1,839,020/2016 pursuant to Resolution 466/2012 of the National Health Council (Conselho Nacional de Saúde). All participants signed the Informed Consent Form to materialize the participation.

\section{RESULTS}

\section{The insertion of the nurse midwife in the setting of teaching maternity}

Regarding the path taken to insert the nurse midwife in the teaching hospital, it is possible to observe citations of some difficulties related to the hiring process of the health professionals (nurse midwives), taking into account the local shortage of specialized professionals for the acting:

There was, then, the need to hire professionals from other places because of the need of the municipality for the insertion of the Stork Network here [...],because had to hire, there was no professional here specialized and there was a need to search in places further away from here, specialization is a requirement. (I3)

In the selection, we had a very difficult time, because we did not have this professional in the municipality, it was a very difficult task to get this professional to hire us ... today all the nurses who work with us as nurse mid wives are not from the city, and this is a daily challenge because the distance messes up a lot, all this dynamics, so l've already had several resignation requests because of this. (18)

There was no professional here specialized, and there was a need to search in places farther away from here, specialization is a requirement. (I15)
Confrontations experienced in the institution related to the hegemonic model of obstetric care, taking into account the path taken with the implantation and the changes in the practices performed by the nurse midwives to follow the delivery focused on the principles of humanization, were clearly evident when the participants highlight the daily difficulties faced that would arise in the process of insertion of these nurse midwives in the teaching hospital.

We left first for risk classification. The initial proposal was to fill the vacancies in the classification of risk, then in a second moment to leave for the nurse midwife performing in the care. (I1)

I know that the obstetric nurse not only has to make admission, but also follow a whole process and she give birth, and we still do not have it here, they are only in admission screening, and we have to go a long way in this. Yes, to advance, because they are only doing the screening we have to walk to the delivery and to be able to make the delivery, I confess that this is my private opinion... (at this moment there is a decrease in the tone of the conversation, starts to speak lower and says he will speak because he knows to be secretive) ... because the nurse cannot make the delivery more humanized (112)

As can be seen, even though the Stork Network was an inducer based on its guidelines and principles, at that time the process of insertion of nurses occurred in a restricted way, with emphasis on risk classification as a prerequisite to be met by the guidelines of the $\mathrm{MoH}$.

The main objective of these hiring for this risk classification was the Stork Network ... it has to have ... because if you are going to fit the molds of Stork Network you have to have in professionals nurse midwives staff, this the program requires you for you to have the qualification, but from there I do not know how the Direction sees the risk classification, as only a staff to meet a requirement. (I10)

We only work with the regulations and standards of risk classification, and so for now we only have this box here to work, always trying to adapt our work to the standards and $\mathrm{MoH}$ manual. (I3)

Nurse midwives can promote changes in their daily lives, but in view of the complexity involved in professional practice that, to some extent, has limitations related to autonomy, institutional support is needed to mediate the operationalization of $\mathrm{MoH} /$ WHO recommendations. Thus, one of the obstacles found was the lack of support from the team (assistance and management), 
in relation to the first hired professionals.

So when we started at the hospital, I already received money from the Stork Network two months before, so we did not have time to train, or a selective process with proof, more specific training.(17)

I passed and began to work, had no training, had a training of a 24-hour shift only, but as in São Gonçalo I went through all sectors of the hospital except for the surgical center that was separated from the obstetric center, I had no major difficulties, just like the others, so it was a training, a 24h-test shift. (13)

Also with regard to the insertion of the nurse midwife in the delivery and birth setting, other difficulties can be observed in the speeches of some participants, especially regarding the need for adaptation of the medical staff and the nursing team itself and the need for space for the respective professional performance with autonomy.

We have been working here for many years without the insertion of the nurse midwife, we think it prudent to go in stages. First adapt all the medical professionals with the obstetric screening, in the practices of the classification of risk, so in a second moment to place an assistant nurse. (11)

Space, we need more space, we need an understanding of the medical team, and also the nursing team, the understanding of our work, so that we can expand our understanding of our true role (autonomy), how it works It is not working apart, it is working together. (14)

The medical staff was not prepared to receive this nurse midwife, and any problem that was going to be a scandal, so what I wanted to do first: an atmosphere, this was my initial, of those nurses doing risk classification and embracement of these patients, that these nurses integrated into the team of obstetricians until this formed bonds of professional confidence (18).

I had already the plan to do, this step by Obstetric Nursing, but I was not successful in the negotiation, the director of the time did not accept, had a tumult, the thing was not well, then I decided to retreat five years ago. What did I want back then? I wanted the preceptorship of motherhood to be performed by a nurse midwife... So I wanted a nurse midwife there as a starting point for the students. At the time I did not think about residency, I thought of a post, a specialization in Obstetric Nursing, but for that I had to guarantee a field of practice. (15)
Another obstacle reported by the participants refers to the conflict between the professional practice of obstetricians and nurse midwives, thus configuring a clash of assistance models coexisting in a single space of performance.

I see today that the biggest difficulty is with medicine itself, because we have very old planners who do practices that do not contemplate the Stork Network and this is a barrier, and even complicated to talk about it ... because the standards that the Network Stork advocates is that childbirth is natural, if childbirth is natural it cannot have induction with medication, which is what we see routinely, because the speech is as follows "let's perform the delivery", so let's put to birth means accelerate this physiological process. (I10)

Nurse midwives can make the delivery more humanized than the doctor, the doctor nowadays, we see, something wrong, of course there are exceptions, I do not know why, but we see this, particularly the obstetrician who does a specialization of these, but is rude there in the accomplishment of childbirth, already teaching this to its residents, when the woman is there in pain, and it seems that she is guilty of being pregnant, there they get rude, I do not understand why that he will do a specialization if he is rude to the woman, so I think the nurse is much more human at this time, we have to move forward a lot. (12)

Actually here it is a teaching hospital, and this makes it difficult for nurses to perform a little, because it is a hospital that is very much concerned with the medical process, and this makes it difficult for nurses to expand in this area. We see in school, in the media, in the most enlightened places, it is the birth of the woman, it is the pregnant woman and not the professional and this culture here does not exist the delivery is the professional, so when I speak change the profile, I talk about changing that, who decides what position she wants to have the baby, if she wants to walk, lie down, if she wins down, who decides this is the woman, and here it is not so... We have very old doctors on duty who do practices that do not contemplate the Stork Network and this is a barrier, and even complicated to talk about it, because the standards that the Stork Network advocates is that the birth is natural, if the birth is natural it does not may have induction with medication, which is what we routinely see, because the speech is the following "let's perform the delivery", so let's put to birth means to accelerate this physiological process. (18)

When it comes to care models, the guiding principles of which are the influences of the technocratic and humanization 
processes that conflict in daily care, there are clues in the participants' statements that point to the need to make explicit practices that give visibility to the professional practice of nurse midwives with a view to the performance of this professional in delivery and birth.

Everyone should understand our true role, to understand how this improvement works, not to work separately, to work together, but to work with another look, for this people need to have this understanding, through lectures, meetings, training of staff as is the understanding of the Stork Network. (17)

It is also worth mentioning that there were also some difficulties encountered by managers in meeting the requirements recommended by the Stork Network/MoH, especially those related to the process of interdependence with local party politics, which ends up being inferred directly in the internal affairs of the institution and in the degree of managerial governance.

Regardless of whether it is the implantation of the Stork Network or any other program, what I see as what makes it difficult for health work is that we do not have technical parameters, people who really are the right people to touch health problems, politics political party interferes a lot with the good progress of health problems and in a disastrous way, because it always generates discontinuity. (I5)

Health should be fully aware of this party political dispute because if you do not see continuity in the actions because you have a period when things are going and suddenly you take the pillars of support mainly teamwork because in health nobody does anything alone, so the success of this work depends on a team very well intertwined, the technical knowledge of each one that generates a whole and that strengthens the patient the person we want to care for. (I1)

For a long time I have been pleading with the management to make the insertion of nurses midwives, even without the advent of the Stork Network, but we were always confronted with the HR and financial situation, and now for political-partisan reasons, because we are in a moment of transition, change of government understand? And there are things that we as managers, we do not have governability about it, so today I still struggle a lot to have 24-hour nurse midwives in the maternity ward. (18)

\section{Expressions of health professionals and managers on the insertion of the nurse midwife in delivery and birth}

It is worth pointing out that, when asked to express their opinions on the main objective of the insertion of nurse midwives in the teaching maternity, the health professionals and managers of the study pointed out the importance of this professional in the transformation into the model of attention to delivery and birth, as understood in the following speeches:

Our goal is not only to serve the Stork Network, we wanted to insert a professional in the maternity that began to give maternity that face of humanized care, of embracing, to treat the pregnant woman not as sick, but as that one arrives to gain a gift, winning a child is a gift, it is the greatest gift, for sure. (I1)

Undoubtedly a better care for pregnant women and parturient, better health condition, embrace, the right to know as a mother, to know the birth, to understand the process that no one explains, who explains is the nursing without doubt, someone to stay with them there to give support, and someone technically prepared to deliver a first-line deliver. (I5)

Several discussions emerged from the statements of managers involved in the insertion of nurse midwives, since in addition to the financial and human resources difficulties encountered by them during the process of insertion of these professionals, it was clear, as discussed in the following statements, that managers expressed numerous opinions to justify the insertion of nurse midwives.

Some managers, through a broader perception regarding the need to implant processes of change of obstetric model, realized the importance of the insertion of the nurse midwife in this context. Expressions emerged that showed that managers recognized the importance of nurse midwives in changing the obstetric model, as shown below:

About 5 years ago I visited Sofia Feldman in Belo Horizonte city and we see that when the team is integrated, everybody wins, the doctor wins, the nursing team wins, the technical support staff wins and mainly the main character wins who is the "mother and baby". Because you have an action that in addition to being integrated, you have different looks about the same situation. (15)

That's why the nurse comes all the better, I'm very much in favor of the nurse because he can be a good manager in what he does, besides being much more human, much more present, different from the doctor who comes there makes and goes away, simple. I know, because I'm a doctor, not a nurse. That's why I need the nurse there. A maternity full of nurse midwives. (I2)

Do we know how much obstetric violence it has, how many procedures are done for misconduct, procedures that should no longer be used, which are already prohibited, 
something like this? I believe that the obstetric nurse has this more humanized look, not that the medical staff does not have it, but it's a different look. (I3)

She contributed to the agility in service and improved access, because when she does not have the nurse midwives, the pregnant women wait hours, this was a contribution of them to these pregnant women. (14)

It is understood that there is much to be done in order for nurse midwives to truly occupy their space at the national level, which will enable holistic care prioritizing women's autonomy and thus facilitating the implementation of non-pharmacological practices and methods for pain relief.

Others express the view of the need to seek the hiring of nurse midwives as a strategy for maintaining and meeting the goals advocated by the Stork Network.

I cannot visualize a nurse who does not deliver in a public hospital that has a qualification like the Stork Network, so I was a bit frustrated at the time because they were only in the risk classification because I believe that the public policies of the MoH evolved to the autonomy of the nurse's work, wanted much more for them. (I9)

The main objective of hiring for this risk classification was the Stork Network, it has to have, because if you are going to fit the molds of Stork Network you have to have nurse midwives in the professional staff, this program requires you to have the qualification, but from there I do not know how the Board sees the risk classification, as only one staff to meet a requirement. (I10)

I believe it was for the initial purpose of implementing the risk classification with the intention of improving the inflow, now improve the assistance therein I believe it is already a fragile thing, because you cannot do it with only one nurse in the embracement and in the classification and a maternity of that size, to give account to improve the assistance, I cannot see this. (I13)

\section{DISCUSSION}

Currently, the "country needs approximately 200 thousand nurse midwives, but it counts on only 5 thousand professionals, in an optimistic estimate"13:1. In this study, one of the greatest conflicts evidenced mentioned the difficulty of finding qualified professionals in the city, being necessary the identification and hiring of nurse midwives from other regions of Rio de Janeiro state.

In Brazil, since the implementation of the Stork Network, a collective effort has been made to qualify and hire nurse midwives by the Health Services. These actions not only cause the expansion of jobs for these professionals in some regions of the country, but also contribute to the implementation of quality care in delivery and birth ${ }^{14}$.

Thus, "investment in training these specialized professionals seeks to portray the successful experience of industrialized countries, where non-medical professionals are the Primary Health Care providers of healthy women during delivery"15:95.

Thus, according to the statements made, we can verify that there was a need to expand the training of nurses, focusing on the specialization in Obstetric Nursing, so that it was possible to obtain better recruitment of these professionals, especially in municipalities outside the Metropolitan Region of Rio de Janeiro state, that face a great challenge for the insertion of these professionals in their Health Units, due to the limited quantitative or even lack thereof.

After the presentation of the results, it is evident that the Stork Network has been one of the major strategies used to insert the nurse midwife in the assistance field to address the reduction of maternal and child mortality, by proposing to change from the current technocratic model to another, more humanized, qualifying the actions and services of health. The Stork Network highlights the need to implant less interventionist practices, changing the current paradigm related to delivery and birth, seeking to place women as protagonists of the parturitive process.

In order for this transformation of the model to take place effectively, there is a need to obtain, in obstetric care, a collaborative assistance between the doctor and the nurse midwife regarding the aspects that involve caring for the woman and the newborn ${ }^{16}$. When conflicts occur that restrict, for example, the nurse midwife's performance, the focus directed to the market dispute contributes to stress the processes that qualify this care ${ }^{14}$

In the setting investigated, statements emerged indicating that nurse midwives have performed only in the risk classification, and their direct insertion for the follow-up of delivery and birth. However, it has legal support to act both in the Embracement and Risk Classification, as in the attention to the usual risk delivery, in addition to postpartum care, as recommended not only by the Stork Network, but also has been determined and guaranteed by Law 7,498 of June 25, 1986 (Professional Nursing Practice) ${ }^{17,18}$.

In this perspective, there are difficulties regarding the insertion of the nurse midwife, both by the medical team and by the nursing team itself. One of the factors may be the lack of knowledge about the legislation that regulates the nurse's performance, besides the conflicts of interest related to the market, given the processes of operationalization of the medical act ${ }^{19}$.

It is appropriate to say that the clash between care models is present in obstetric care, where the nurse performs care based on the principles of humanization, while the obstetrician tends to implement, historically, practical influences by the technocratic model to the care of women, thus perpetuating "delivery as the supremacy of the technique"20:256. This model sums up with the idea of "man controlling nature"20, thus, delivery is controlled by innumerable interventions in the woman's body, such as cesarean section, episiotomy, medicalization, among 
others ${ }^{20}$. And today there is a logic of decreasing unnecessary interventions in care for women, delivery and birth, as advocated by $\mathrm{WHO}^{6,7}$.

Thus, "the concept of humanization for Obstetric Nursing involves attitudes, practices, behaviors and knowledge based on the healthy development of the process of delivery and birth"21:2. In this way, the physiology of women is respected, respecting their autonomy and the right to a respectful birth, according to their expectations, translating a care with security, perpetuating a respectful attention to the woman regarding her dignity and privacy, assuring all necessary support for humanized care ${ }^{6,7}$.

It is noted that the insertion of the nurse midwife has several obstacles, such as those related to administrative, financial, human resources, but above all, to inequalities in power relations. It is possible to perceive the lack of autonomy of some managers in relation to the insertion of the nurse midwife in delivery and birth and the lack of autonomy of the worker herself regarding the understanding of her professional practice. In this sense, the autonomy of the nurse tends to be represented as something that is not yet completely established, and yet is not represented as absent or non-existent ${ }^{22}$.

Therefore, the support of managers becomes essential for the insertion of the nurse midwife, especially when it is placed "on the shoulders of this worker" prominence related to the degree of responsibility to change an existing model. Thus, there is a need for a set of forces that contributes to the nurse to face the circumstantial difficulties for the development of her practices, given that there is legal support for her performance, such as her recommendation through her guidelines WHO at delivery and birth ${ }^{6,7}$.

Continuing the discussion of the data, the obstacles encountered by managers for the insertion of nurse midwives in the maternity care setting are better understood, given the information that the study setting is a teaching hospital, whose main characteristic is the a doctor-centered care model as the primary provider of care for delivery and birth, and therefore responsible for high rates of cesarean sections and interventions in delivery and birth.

Contradictory, it is important to highlight that teaching hospitals have as their main characteristic the responsibility of the training process of the professionals involved. However, this fact has been pointed out as a difficult factor for the change of the care model to a more humanized practice and free of unnecessary interventions ${ }^{23}$. See the empirical justification related to the emphasis on the need for teaching/learning technocratic techniques and procedures.

However, from the analysis of the interviewees' speeches, it was evidenced that the insertion of the nurse midwife in delivery and birth, in dialogue with the valuation of humanized delivery, contributes to increase not only the autonomy and the decision power of the pregnant woman, in a less authoritarian relationship, but also causes questions that allow the insertion of this professional. In this regard, the process of implanting nursing technologies for pain relief ${ }^{24}$ and discouraging the use of interventions deemed unnecessary, in accordance with international and national recommendations $s^{3,4,6,7}$.

Another point that has emerged in the speeches is directed to the influences of the political-partisan disputes that occur, resulting in interferences in the health process and in the internal decisions of the hospital environment. This contributes to diminishing the governance of those who are at the forefront of the process, causing difficulties to reach the goals recommended by the Ministry of Health and $\mathrm{WHO}^{4-7}$. Thus, there is a need for managers and health professionals to be really at the forefront of this process, not suffering from party interference, thus contributing to the continuity of care of the teams, as well as to the quality offered to the population.

It is noteworthy that even in times of crisis and in the face of so many difficulties, Brazil was able to maintain "social demands through a set of public interventions aimed at promoting well-being from a comprehensive, universal and free health system, involving popular participation in the various collegial decision-making spheres"25:10. However, it is worth emphasizing that a better articulation between the three spheres of public power (Municipal, State and Federal) is necessary for effective communication and effective oversight of the programs by the higher spheres, so that there is no discontinuity of the actions proposed by them and waste of public resources, increasingly scarce. In this way, the process of decentralization of the State and the benefits gained for health ${ }^{26}$.

Ensuring the construction of a network of changes for the insertion of the nurse midwife depends on a collective work with managers, professionals and, above all, a challenge for every society, because "humanized care for delivery refers to the need to a new look, understanding it as a truly human experience. Embracing, listening, guiding and creating bonds are fundamental aspects in the care of women, in this context"21:2.

The expressions of health professionals and managers about the insertion of nurse midwives show the difficulties in this transformation of the care model, but it is perceived that this transition from a traditional model that lasts for so many years can be shared between the teams, provided that the obstacles encountered are discussed among managers and health professionals.

This transformation from a care model to a collaborative model means a shift in obstetric care where the integration of obstetrician and nurse midwife occurs ${ }^{16}$. The results showed that the managers involved in the insertion of these nurses perceived how this professional was important for the change to occur. It can also be observed that statements have emerged indicating that the transformation is important for the reduction of the unnecessary interventions both faced ${ }^{4-7}$, which would happen through insertion of these professionals in the setting of delivery and birth and not only in the Embracement and Risk Classification.

The strategies established by the managers for this insertion in the teaching hospital occurred in a gradual way. The results show that, firstly, it occurred in the Embracement and Risk Classification, being indicated positive expressions. Compared to a study carried out on the implementation of the host module 
of the Programa Cegonha Carioca (freely translated as Carioca Stork Program, it is a pioneering project in Brazil, implemented in 2011, the Carioca Stork has as main objectives to humanize and guarantee the best care for mother and baby) in the city of Rio de Janeiro, the difference between municipalities. "It should be noted that the six maternity hospitals in the city of Rio de Janeiro, where the modules of the host and risk classification module were initially implanted, already had nurse midwives working in the delivery room, which allowed this accumulation of practical experiences"27:3942.

It is noteworthy that in the city of Rio de Janeiro, the path was the opposite to that followed in the municipality of the Mountain Region of Rio de Janeiro state, where the implantation took place first in the Embracement and Risk Classification Module ${ }^{27}$. The fact that they already have nurse midwives working in the delivery room has enabled an experience in the work space, together with the embracement of the team and the specialized professionals available. It can be inferred that public management strategies facilitated the implementation process of the Programa Cegonha Carioca ${ }^{27}$.

Managers who participated in the hiring at the teaching hospital investigated were administrative and educational coordination managers. All of them demonstrated the same perception about the nurse midwives, expressing recognition that only with their actions would they be able to promote the change in the care model, with emphasis on collective team growth, improved care for women, improved access flow and in the paradigm that involves delivery and birth.

It can be observed, according to the participants' statements, that the insertion of the nurse midwives was performed based on the priority given to the requirements of the Stork Network, with a view to ensuring the transfer of resources through the Ministry of Health. It was evidenced, in the professionals' statements, that the Stork Network had a preponderant role in the insertion of the nurse midwives and that the initial strategy was in the Embracement and Risk Classification, having the desired effect with regard to the improvement of the access and embracement to the pregnant women. At this point, it is worth mentioning that when the nurse midwife technically prepared to provide quality obstetric care makes it possible to promote changes in institutional practices and routines.

In analyzing the conflicts expressed in the statements, it was noticed that, in the view of health professionals, the greatest challenges encountered in the insertion process were the structural and autonomy issues in the nurse's professional performance, mainly in relation to the lack of understanding of the medical staff and of the nursing team itself regarding the "capacity" of professional performance of nurse midwives.

Both health professionals and managers agreed that there was initially a conflict between obstetricians and nurse midwives because there was no prior preparation with presentations and clarifications about the true role of these professionals in the routine of maternity.

However, the impression left by the interview analysis is that, even in the face of the conflicts initially faced by both parties, nurse midwives have brought quality processes, agility, resolution and humanized care to pregnant women, even though they are restricted to risk classification.

The study provides support to managers and health professionals and education - hospital in focus is teaching - with a view to strengthening and implementing public health policies related to delivery and birth. Even though the approach to the logic of the reconfiguration of care in motherhood from the insertion of the nurse midwife has been highlighted in this case study, it is understood that the difficulty found in interviewing some managers of the municipal sphere (see political-party change occurred during collection of information with substitution of professional positions) and the research process was located in an institution contributes to find limitations that point to the need to replicate the research in other settings, especially with a larger number of professionals.

\section{CONCLUSION}

The results showed that the Stork Network was an important strategy in the process of insertion of nurse midwives in the investigated teaching hospital, in agreement with the recommendations recommended by the Ministry of Health and the World Health Organization.

In the researched setting, the insertion process of nurse midwives was experienced by difficulties such as the lack of specialized professionals; absence of space for nurse midwives performance and autonomy; political-party aspects influencing institutional management; conflict of practice with obstetricians; and lack of nurses in the delivery room. The initial strategy used was the insertion of these professionals first in the Embracement and Risk Classification. However, the deponents expressed that this measure was considered positive, because even if the nurses were not performing directly in the delivery and birth, the respective performances in the embracement and classification were able to induce changes in the health practices, the access of the women, in the resolution in the attendance and recognition of the professional performance by the doctors.

Thus, the study shows that nurse care in obstetric care reinforces the important contribution of this professional in relation to the practice of care, in accordance with the recommendation of humanized care at delivery and birth. In addition, it is able to reconfigure the care model, contributing to changes through an autonomous, collaborative and quality action in compliance with national and international public health policies.

\section{REFERENCES}

1. Medeiros RMK, Teixeira RC, Nicolini AB, Alvares AS, Corrêa ACA, Martins DP. Cuidados humanizados: a inserção de enfermeiras obstétricas em um hospital de ensino. Rev Bras Enferm [Internet]. 2016 Nov-Dec; [cited 2018 Jun 13]; 29(6):1091-8. Available from: http://www.scielo.br/pdf/reben/v69n6/0034-7167reben-69-06-1091.pdf. DOI: http://dx.doi.org/10.1590/0034-71672016-0295 
2. Souza AMM, Souza KV, Rezende EM, Martins EF, Campos D, Lansky S. Práticas na assistência ao parto em maternidades com inserção de enfermeiras obstétricas, em Belo Horizonte, Minas Gerais. Esc Anna Nery [Internet]. 2016 Apr-Jun; [cited 2018 Jun 13];20(2):324-31. Available from: http://www.scielo.br/pdf/ean/v20n2/1414-8145-ean-20-02-0324.pdf. DOI: http://dx.doi.org/10.5935/1414-8145.20160044

3. Vargens OMC, Silva ACV, Progianti JM. Contribuição de enfermeiras obstétricas para consolidação do parto humanizado em maternidades no Rio de Janeiro-Brasil. Esc Anna Nery [Internet]. 2017; [cited 2018 Jun 13] 21(1):e20170015. Available from: http://www.scielo.br/pdf/ean/v21n1/14148145-ean-21-01-e20170015.pdf. DOI: http://dx.doi.org/10.5935/14148145.20170015

4. Ministério da Saúde (BR). Secretaria de Ciência, Tecnologia e Insumos Estratégicos. Diretrizes nacionais de assistência ao parto normal: versão resumida. Brasília: Ministério da Saúde; 2017.

5. Côrtes CT, Santos RCS, Caroci AS, Oliveira SG, Oliveira SMJV, Riesco MLG. Metodologia de implementação de práticas baseadas em evidências científicas na assistência ao parto normal: estudo piloto. Rev Esc Enferm USP [Internet]. 2015; [cited 2018 Jun 13]; 49(5):716-25. Available from: http://www.scielo.br/pdf/reeusp/v49n5/pt_0080-6234-reeusp-49-05-0716. pdf. DOI: http://dx.doi.org/10.1590/S0080-623420150000500002

6. World Health Organization. WHO recommendations: intrapartum care for a positive childbirth experience. Geneva:World Health Organization;2018.

7. World Health Organization. Recomendaciones de la OMS para los cuidados durante el parto, para una experiencia de parto positiva. Geneva: World Health Organization; 2018.

8. Minayo MCS. O Desafio da pesquisa social. In: Deslandes SF, Gomes R, Minayo MCS, orgs. Pesquisa social: Teoria, método e criatividade. $34^{\mathrm{a}} \mathrm{ed}$ Petrópolis: Vozes; 2014.

9. Demo P. Metodologia da Investigação em Educação. Curitiba: Intersaberes; 2013.

10. Lima DVM. Desenho de uma pesquisa: uma contribuição para autores. Online Braz J Nurs [Internet]. 2011 Oct; [cited 2018 Jun 13]; 10(2):1-20. Available from: http://www.objnursing.uff.br/index.php/nursing/article/ view/3648/html. DOI: https://doi.org/10.5935/1676-4285.20113648

11. Hospital de Ensino Alcides Carneiro [Internet]. Histórico da unidade hospitalar. Petrópolis: Hospital de Ensino Alcides Carneiro; 2015 [cited 2018 Jun 10]. Available from: http://www.alcidescarneiro.com/institucional/ historico\%20Hac.pdf

12. Bardin L. Análise de conteúdo. $4^{a}$ ed. Lisboa: Edições 70; 2011.

13. Conselho Regional de Enfermagem do Mato Grosso do Sul. Brasil precisa de milhares de enfermeiros obstetras, diz palestrante. [Internet]. 2016 Mar 17; [cited 2018 Jun 10]. Available from: http://ms.corens. portalcofen.gov.br/brasil-precisa-de-milhares-de-enfermeiros-obstetrasdiz-palestrante_6227.html

14. Lima GPV, Pereira ALF, Guida NFB, Progianti JM, Araújo CLF, Moura MAV. Expectativas, motivações e percepções das enfermeiras sobre a especialização em enfermagem obstétrica na modalidade residência. Esc Anna Nery [Internet] 2015 Oct-Dec; [cited 2018 Jun 13]; 19(4):5939. Available from: http://www.scielo.br/pdf/ean/v19n4/1414-8145ean-19-04-0593.pdf.DOI: http://dx.doi.org/10.5935/1414-8145.20150079

15. Reis TR, Zamberlan C, Quadros JS, Grasel JT, Moro ASS. Enfermagem obstétrica: contribuições às metas dos Objetivos de Desenvolvimento do Milênio. Rev GaúchaEnferm [Internet].2015; [cited 2018Jun 13];36(esp.):94101. Available from: http://www.scielo.br/pdf/rgent/v36nspe/0102-6933rgenf-36-spe-0094.pdf. DOI: http://dx.doi.org/10.1590/1983-1447.2015. esp. 57393

16. Vogt SE, Silva KS, Dias MAB. Comparação de modelos de assistência ao parto em hospitais públicos. Rev Saúde Pública [Internet]. 2014; [cited 2018 Jun 13]; 48(2):304-13. Available from: http://www.scielo. br/pdf/rsp/v48n2/0034-8910-rsp-48-2-0304.pdf. DOI: 10.1590/S00348910.2014048004633
17. Oliveira FAM, Leal GCG, Wolff LDG, Rabelo M, Poloquesi CB. Reflexões acerca da atuação do enfermeiro na rede cegonha. Rev Enferm UFPE On Line [Internet]. 2016 Feb; [cited 2018 Jun 13]; 10(Supl 2):867-74. Available from: https://periodicos.ufpe.br/ revistas/revistaenfermagem/article/view/11030/12421.DOI: 10.5205/ reuol.6884-59404-2-SM-1.1002sup201622

18. Ministério da Saúde (BR). Portaria no 2815, de 29 de maio de 1998. DOU 103, de 2/6/98. Considerando o disposto na Lei 7.498 de 25 de junho de 1986, que regulamenta o exercício da enfermagem e no Decreto $n 94406$ de 08 de junho de 1987, que define as atribuições do enfermeiro obstetra. Brasília: Diário Oficial da União; 1998

19. Garcia SAL, Garcia SAL, Lippi UG. A necessidade de inserção do enfermeiro obstetra na realização de consultas de pré-natal na rede pública. Einstein [Internet]. 2010; [cited 2018 Jun 13]; 8(2 Pt 1):241-7. Available from: http://www.scielo.br/pdf/eins/v8n2/ pt_1679-4508-eins-8-2-0241.pdf. DOI: http://dx.doi.org/10.1590/ s1679-45082010rw1486

20. Mendonça SS. Modelos de assistência obstétrica concorrentes e ativismo pela humanização do parto. Civitas [Internet]. 2015 Apr-Jun; [cited 2018 Jun 13]; 15(2):250-71. Available from: http://revistaseletronicas.pucrs.br/ojs/index.php/civitas/article/ view/17899/13392. DOI: http://dx.doi.org/10.15448/19847289.2015.2.17899

21. Possati AB, Prates LA, Cremonese L, Scarton J, Alves CN, Ressel LB. Humanização do parto: significados e percepções de enfermeiras. Esc Anna Nery [Internet]. 2017 [cited 2018 Jun 13] 21(4):e20160366. Available from: http://www.scielo.br/pdf/ean/v21n4/ pt_1414-8145-ean-2177-9465-EAN-2016-0366.pdf. DOI: http:// dx.doi.org/10.1590/2177-9465-EAN-2016-0366

22. Sena CD, Santos TCS, Carvalho CAF, Sá ACM, Paixão GPN. Avanços e retrocessos da enfermagem obstétrica no Brasil. Rev Enferm UFSM [Internet]. 2012 Sep-Dec; [cited 2018 Jun 13]; 2(3):523-9. Available from: https://periodicos.ufsm.br/reufsm/article/view/3365/pdf. DOI http://dx.doi.org/10.5902/217976923365

23. Monticelli M, Brüggemann OM, Guerini IC, Boing AF, Padilha MF, Fernandes VB. A filosofia assistencial da maternidade de um hospital universitário na visão dos acadêmicos. Texto Contexto Enferm [Internet]. 2010 Jan-Mar; [cited 2016 Apr 14]; 19(1):25-35. Available from: http://www.scielo.br/pdf/tce/v19n1/v19n1a03. DOI: http://dx.doi. org/10.1590/S0104-07072010000100003

24. Diniz CSG. Humanização da assistência ao parto no Brasil: os muitos sentidos de um movimento. Ciênc Saúde Coletiva [Internet]. 2005 [cited 2018 Apr 14]; 10(3):627-37. Available from: http://www.scielo.br/ pdf/csc/v10n3/a19v10n3.pdf. DOI: http://dx.doi.org/10.1590/S141381232005000300019

25. Pessoto UC, Ribeiro EAW, Guimarães RB. O papel do Estado nas políticas públicas de saúde: um panorama sobre o debate do conceito de Estado e o caso brasileiro. Saúde Soc [Internet]. 2015 [cited 2018 Jun 13]; 24(1):9-22. Available from: http://www.scielo.br/ pdf/sausoc/v24n1/0104-1290-sausoc-24-1-0009.pdf. DOI: 10.1590/ S0104-12902015000100001

26. Cavalcanti PCS, Gurgel Junior GD, Vasconcelos ALR, Guerrero AVP. Um modelo lógico da Rede Cegonha. Physis [Internet]. 2013; [cited 2018 Jun 13]; 23(4):1297-316. Available from: http://www.scielo. br/pdf/physis/v23n4/14.pdf. DOI: http://dx.doi.org/10.1590/S010373312013000400014

27. Sé CCS, Progianti JM, Pereira ALF. Implantação do módulo acolhimento do programa cegonha carioca no município do Rio de Janeiro. J Res Fudam Care Online [Internet]. 2016; [cited 2018 Jun 13]; 8(1):3935-44. Available from: http://www.seer.unirio.br/index.php/ cuidadofundamental/article/view/3375/pdf_1814. DOI: 10.9789/21755361.2016.v8i1.3935-3944 